\title{
KOMUNIKASI MATEMATIKA TERTULIS SISWA MA BERKEMAMPUAN MATEMATIKA TINGGI DALAM PEMECAHAN MASALAH BERDASARKAN JENIS KELAMIN
}

\author{
Arezqi Tunggal Asmana \\ Pendidikan Matematika, FKIP, Universitas Islam Darul 'Ulum Lamongan \\ arezqitunggal@unisda.ac.id
}

\begin{abstract}
Abstrak
Penelitian ini bertujuan untuk mendeskripsikan komunikasi matematika tertulis siswa MA berkemampuan matematika tinggi dalam pemecahan masalah soal persamaan lingkaran berdasarkan jenis kelamin. Penelitian ini adalah penelitian kualitatif dengan data utama tentang keakuratan, kelengkapan, dan kelancaran komunikasi matematika tertulis berupa katakata tertulis. Subjek penelitian sebanyak 2 siswa berkemampuan matematika tinggi kelas XI MIPA MAN 1 Lamongan yang terdiri dari satu siswa laki-laki dan perempuan. Hasil penelitian menunjukkan bahwa adanya sedikit perbedaan komunikasi matematika tertulis siswa laki-laki dengan perempuan. Keakuratan dan kelancaran komunikasi matematika tertulis siswa laki-laki dan perempuan berkemampuan matematika tinggi adalah sama-sama akurat dan lancar untuk setiap informasi yang disampaikan. Kelengkapan komunikasi matematika tertulis siswa perempuan berkemampuan matematika tinggi adalah lengkap untuk setiap informasi yang disampaikan sedangkan siswa laki-laki hanya tidak lengkap untuk menggunakan aturan.
\end{abstract}

Kata Kunci: komunikasi matematika tertulis, pemecahan masalah, jenis kelamin.

\begin{abstract}
This study aims to describe written mathematics communication of high mathematical ability MA students in problem solving about the equation of circles based on gender. This research is qualitative research with the main data about the accuracy, completeness, and fluency of written mathematics communication in the form of written words. The research subjects were 2 students with high mathematical abilities in class XI MIPA MAN 1 Lamongan consisting of one male and female student. The results show that there was a slight difference in written mathematics communication between male and female students. The accuracy and fluency of written mathematics communication of male and female students with high mathematical abilities are equally accurate and fluent for each information delivered. Completeness of written mathematics communication of female students with high mathematical abilities is complete for each information delivered while male students are only incomplete to use the rules.
\end{abstract}

Keywords: written mathematics communication, poblem solving, gender. 


\section{PENDAHULUAN}

NCTM (2000) menyatakan bahwa standar proses dalam pembelajaran matematika, meliputi pemecahan masalah, penalaran dan pembuktian, komunikasi, koneksi, dan representasi. Selanjutnya NCTM (2000) menyatakan bahwa terdapat komunikasi yang merupakan bagian penting dari matematika. Menurut Hirschfeld-Cotton (2008), komunikasi membantu untuk membangun makna ketika siswa ditantang untuk berpikir dan bernalar, kemudian mengomunikasikan ide-ide mereka secara lisan maupun tertulis sehingga pemahaman konseptual yang benar berkembang.

Menurut Caballero dkk. (2011), komunikasi dari proses dan hasil termasuk kemampuan untuk mengirimkan secara cukup tepat bahasa lisan dan tertulis, ide-ide dan proses yang dikembangkan sehingga mereka dapat dipahami. NCTM (2000) menyatakan bahwa komunikasi adalah suatu fitur/ciri penting pada saat siswa mengekspresikan hasil pemikiran mereka secara lisan maupun tertulis. Bansu (dalam Agustyaningrum, 2011) menelaah komunikasi menjadi komunikasi lisan dan komunikasi tertulis. Komunikasi lisan diungkap melalui intensitas keterlibatan siswa dalam kelompok kecil selama berlangsungnya proses pembelajaran sedangkan komunikasi tertulis melalui kemampuan dan keterampilan siswa menggunakan kosakata dan notasi serta struktur untuk menyatakan gagasan dan memahaminya dalam memecahkan masalah.

Berfokus pada komunikasi tertulis, Dewi (2009) mengatakan komunikasi matematika tertulis adalah proses penyampaian ide/pikiran matematika yang diwujudkan dalam bentuk tulisan. Menurut Dewi (2009), keakuratan dan kelengkapan informasi sangat diperlukan dalam komunikasi matematika serta kelancaran yang diperlukan dalam menyampaikan informasi tersebut. Selanjutnya Dewi (2009) mengatakan semakin sering siswa mengkomunikasikan ide/pikirannya tentang suatu materi maka semakin menajamkan pemahaman mereka tentang materi tersebut.

Menurut Kim dan Noh (2010), secara umum ada korelasi linear konsisten antara pemahaman masalah terhadap proses pemecahan masalah dan keterampilan 
komunikasi. Selanjutnya Polya (1973) mengatakan langkah-langkah pemecahan masalah, yaitu: (1) memahami masalah; (2) membuat rencana; (3) melaksanakan rencana; dan (4) memeriksa kembali.

Pada dasarnya setiap peserta didik memiliki kemampuan matematika yang berbeda-beda sehingga komunikasi dalam pemecahan masalah matematika diduga berbeda (Asmana, 2018). Itu juga didukung beberapa hasil penelitian sebelumnya yang relevan. Salah satunya hasil penelitian oleh Dewi (2009), yaitu adanya perbedaan komunikasi matematika untuk mahasiswa laki-laki dan perempuan berkemampuan matematika tinggi, sedang, dan rendah. Sejalan dengan itu, hasil penelitian Venkatesh Kumar \& Karimi (2010) yang menunjukkan perbedaan pencapaian matematika dalam pemecahan masalah antara siswa laki-laki dan perempuan. Begitu pula hasil penelitian Zhu (2007) menunjukkan terdapat perbedaan kemampuan memecahkan masalah matematika antara laki-laki dan perempuan.

Nugroho dkk. (2018) mengatakan secara garis besar anak laki-laki lebih baik dalam penalaran sedangkan anak perempuan lebih dalam hal ketepatan, ketelitian, kecermatan, dan keseksamaan berpikir. Dari pendapat para ahli dapat disimpulkan bahwa perbedaan jenis kelamin tidak lagi hanya berkaitan dengan faktor biologis saja tetapi sudah berkembang menjadi perbedaan kemampuan antara laki-laki dan perempuan (Lutfiyah dkk., 2018).

Berdasarkan hal di atas, terdapat komunikasi dan pemecahan masalah matematika yang sangat penting ditumbuhkembangkan di kalangan siswa. Sebagai modal awal, untuk menumbuhkembangkan komunikasi matematika tertulis sehingga dapat digunakan sebagai pedoman untuk mengupayakan pembelajaran yang lebih tepat, diperlukan pengetahuan tentang komunikasi matematika tertulis siswa. Dengan meninjau perbedaaan jenis kelamin serta masih sedikitnya penelitian di Madrasah Aliyah (MA) sehingga peneliti ingin mengadakan penelitian tentang "Komunikasi Matematika Tertulis Siswa MA Berkemampuan Matematika Tinggi dalam Pemecahan Masalah Berdasarkan Jenis Kelamin”.

Penelitian ini bertujuan untuk mendeskripsikan komunikasi matematika tertulis siswa laki-laki dan perempuan berkemampuan matematika tinggi dalam pemecahan masalah. Aspek komunikasi 
matematika tertulis yang diamati yakni keakuratan, kelengkapan, dan kelancaran informasi yang disampaikan dalam pemecahan masalah. Informasi tersebut, yaitu menuliskan hal-hal yang diketahui dan ditanya, membuatkan gambar/sketsa, menggunakan aturan, melakukan perhitungan, dan membuatkan kesimpulan (Asmana, 2018). Jenis penelitian ini adalah deskriptif eksploratif yang bersifat kualitatif. Analisis dilakukan secara mendalam pada siswa MA berkemampuan matematika tinggi untuk mendeskripsikan komunikasi matematika tertulis dalam pemecahan masalah matematika dengan materi persamaan lingkaran berdasarkan jenis kelamin.

Penelitian ini dilakukan di kelas XI MIPA MAN 1 Lamongan dari bulan April sampai dengan bulan Mei 2018. Subjek penelitian adalah 2 siswa kelas XI MIPA MAN 1 Lamongan semester genap tahun ajaran 2018/2019 yang masingmasing terdiri dari satu siswa laki-laki dan perempuan berkemampuan matematika tinggi. Penentuan subjek penelitian menggunakan Tes Kemampuan Matematika (TKM). TKM berupa 20 butir soal UNBK 2 tahun terakhir dengan materi yang sudah diajarkan dan dianggap layak oleh teman sejawat (dosen) dan guru kelas. Setiap butir soal diberi skor 5 sehingga keseluruhan jawaban memiliki skor dengan skala 0 sampai 100.

Instrumen utama adalah peneliti sendiri. Peneliti sebagai pengumpul data, menginterpretasi data melalui pengamatan langsung dan wawancara. Dalam penelitian ini digunakan instrumen pendukung. Instumen pendukung 1 berupa Tes Pemecahan Masalah (TPM), instrumen pendukung 2 berupa pedoman wawancara, dan instrumen pendukung 3 berupa alat perekam.

Sebelum digunakan, TPM dan pedoman wawancara divalidasi oleh teman sejawat (dosen) dan guru kelas. TPM yang valid diberikan kepada subjek penelitian sehingga diperoleh data berupa jawaban tertulis. Kemudian data tersebut dianalisis. Teknik analisis data yang dilakukan adalah analisis isi (content analysis), yaitu memeriksa keakuratan, kelengkapan, kelancaran jawaban tertulis yang diberikan subjek, diidentifikasi apakah jawaban yang diberikan sesuai dengan kriteria informasi yang disampaikan. Kemudian data diperiksa kredibilitas dengan cara triangulasi metode, ketekunan pengamatan, kecukupan referensial, dan triangulasi waktu. 


\section{HASIL DAN PEMBAHASAN}

Subjek pada penelitian ini diambil 2 siswa kelas XI MIPA MAN 1 Lamongan yang disajikan pada Tabel 1 .

Tabel 1. Subjek Penelitian

\begin{tabular}{ccc}
\hline $\begin{array}{c}\text { Inisial } \\
\text { Subjek }\end{array}$ & $\begin{array}{c}\text { Jenis } \\
\text { Keamin }\end{array}$ & $\begin{array}{c}\text { Kode } \\
\text { Subjek }\end{array}$ \\
\hline HZA & L & LT \\
HS & P & PT
\end{tabular}

Kedua subjek penelitian di atas diberikan TPM 1 pada pengambilan data pertama dan TPM 2 pada pengambilan data kedua. Kemudian hasil yang diperoleh sebagai berikut.

\section{Komunikasi Matematika Tertulis}

\section{Subjek LT}

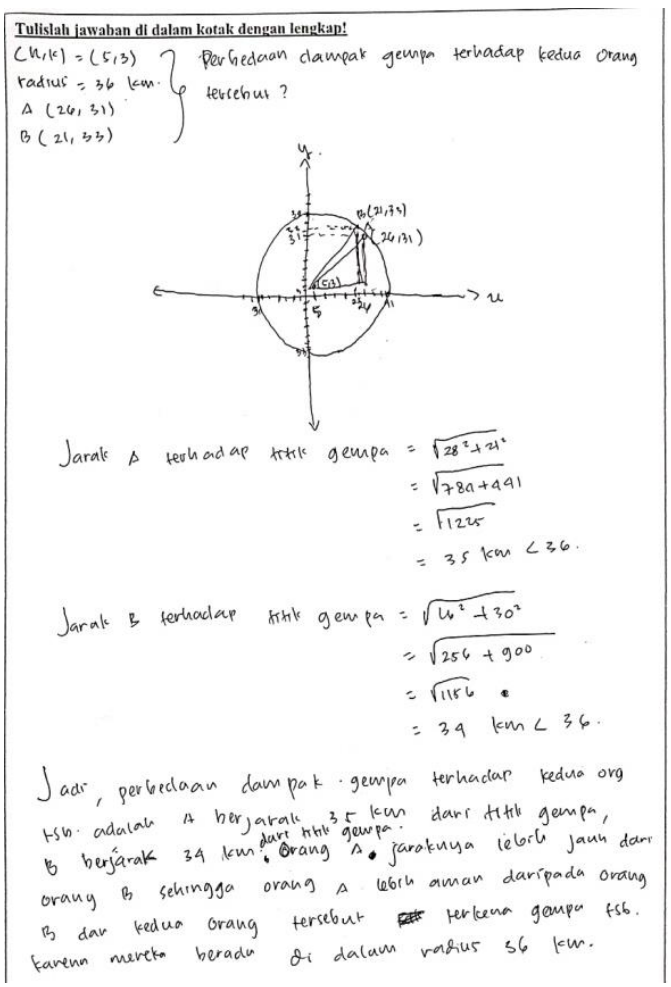

Gambar 1. KMT LT untuk TPM 1
Berdasarkan Gambar 1, keakuratan komunikasi matematika tertulis LT menunjukkan akurat untuk setiap informasi yang disampaikan, yaitu menuliskan hal-hal yang diketahui dan ditanya, membuatkan gambar/sketsa, menggunakan aturan, melakukan perhitungan, dan membuatkan kesimpulan. Hal itu sesuai untuk hasil TPM 2 yang disajikan pada Gambar 2.

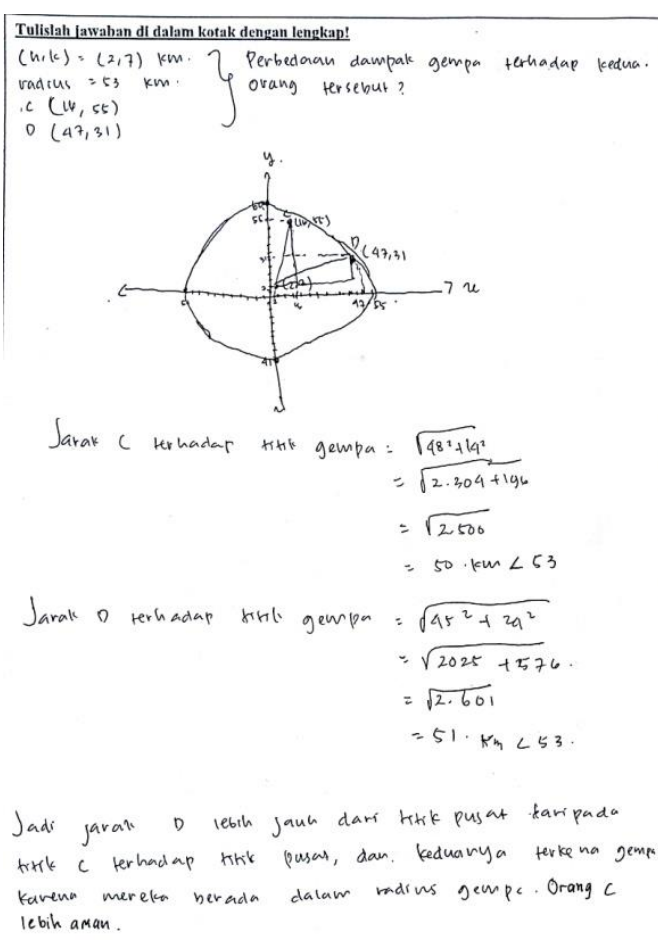

Gambar 2. KMT LT untuk TPM 2

Berdasarkan Gambar 1 dan 2, kelengkapan komunikasi matematika tertulis LT menunjukkan hanya tidak lengkap untuk menggunakan aturan. Hal itu sesuai dengan jawaban pada saat wawancara. Berikut cuplikan wawancara pada langkah membuat rencana. 


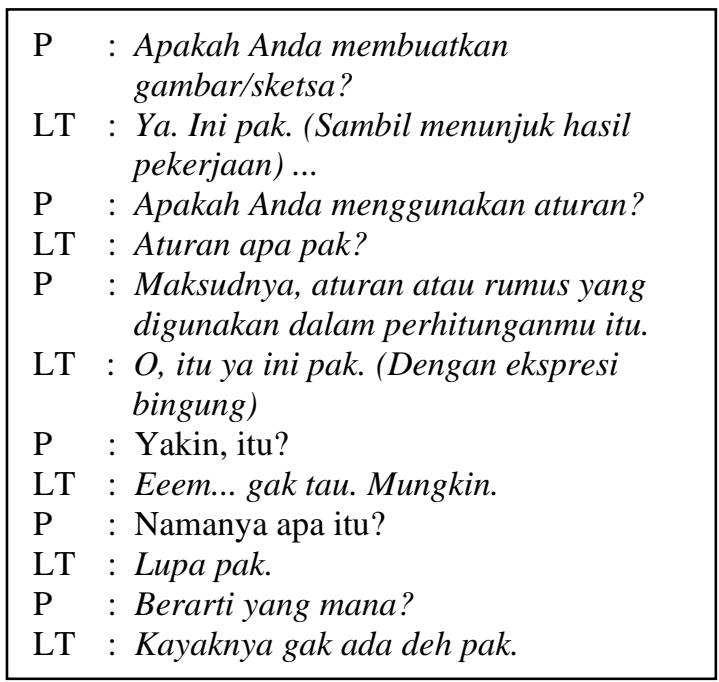

Berdasarkan Gambar 1 dan 2 serta hasil wawancara, kelancaran komunikasi matematika tertulis LT menunjukkan lancar untuk menyampaikan informasi sampai tujuan akhir dengan batas waktu yang diberikan. Hal itu sejalan dengan hasil penelitian Lestari dkk. (2019) yang menunjukkan bahwa komunikasi matematika tertulis siswa laki-laki hanya tidak lengkap pada langkah membuat rencana. Akan tetapi hal itu sedikit berbeda. Pada langkah membuat rencana, informasi yang disampaikan berupa membuatkan gambar/sketsa dan menggunakan aturan. Pada langkah tersebut, siswa laki-laki berkemampuan matematika tinggi tidak lengkap untuk membuatkan gambar/sketsa sedangkan hasil penelitian peneliti tidak lengkap untuk menggunakan aturan.

\section{Komunikasi Matematika Tertulis Subjek PT}

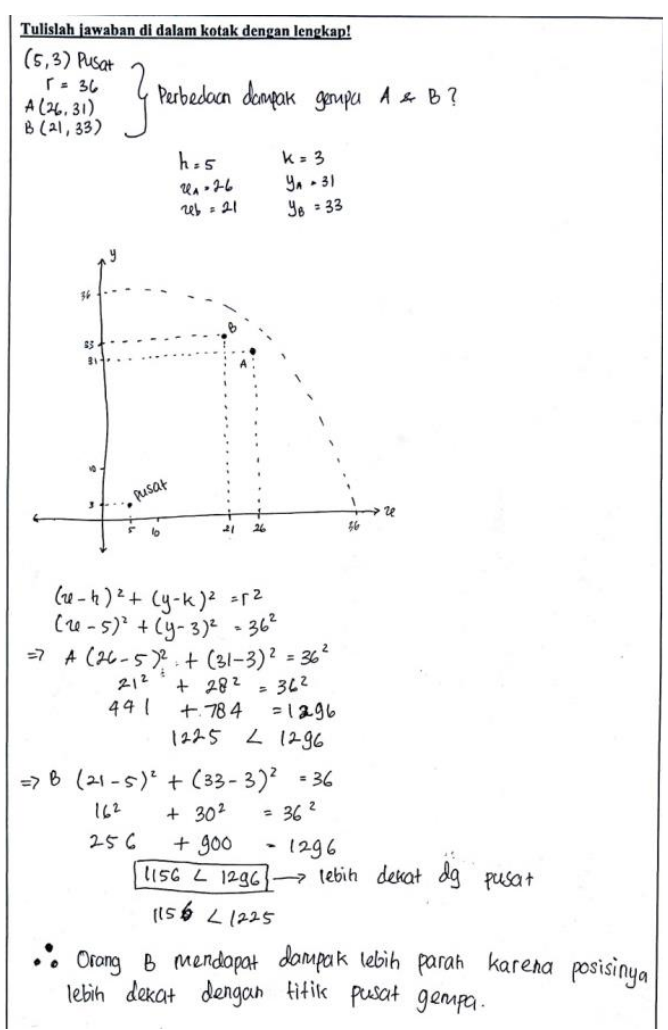

Gambar 3. KMT PT untuk TPM 1

Berdasarkan Gambar 3, keakuratan komunikasi matematika tertulis PT menunjukkan akurat untuk setiap informasi yang disampaikan, yaitu menuliskan hal-hal yang diketahui dan ditanya, membuatkan gambar/sketsa, menggunakan aturan, melakukan perhitungan, dan membuatkan kesimpulan. Kelengkapan komunikasi matematika tertulis PT menunjukkan lengkap untuk setiap informasi yang disampaikan. Hal itu sesuai pada saat 
wawancara serta hasil TPM 2 oleh PT yang disajikan pada Gambar 4.

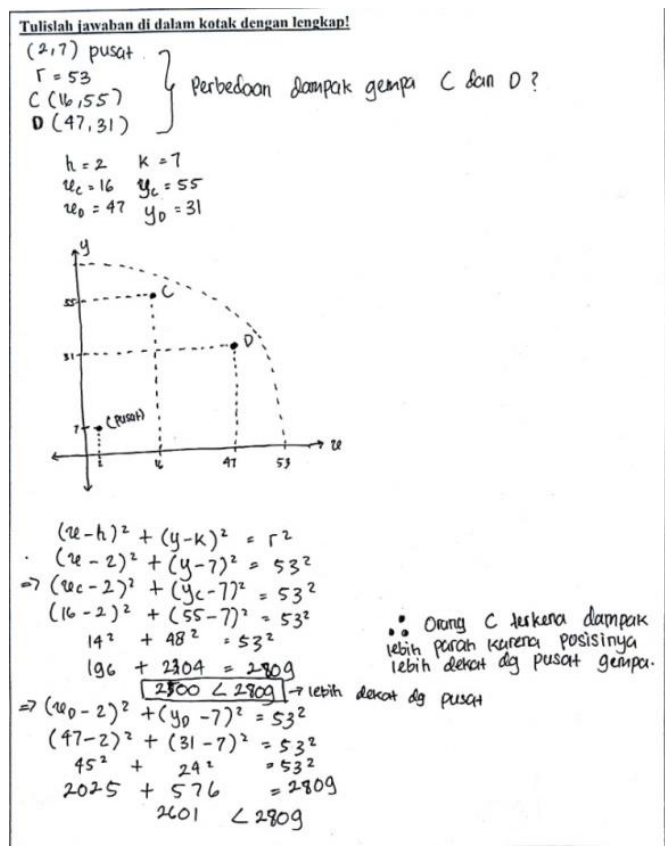

Gambar 4. KMT PT untuk TPM 2

Berdasarkan Gambar 3 dan 4 serta hasil wawancara, kelancaran komunikasi matematika tertulis PT menunjukkan lancar untuk menyampaikan informasi sampai tujuan akhir dengan batas waktu yang diberikan. Hal itu sejalan dengan hasil penelitian Isroil dkk. (2017) yang menunjukkan siswa berkemampuan matematika tinggi sangat baik dalam pemecahan masalah.

\section{SIMPULAN}

Berdasarkan hasil analisis data dan pembahasan dapat disimpulkan komunikasi matematika tertulis siswa laki-laki dan perempuan berkemampuan matematika tinggi tentang keakuratan, kelengkapan, dan kelancaran komunikasi matematika tertulis dengan informasi yang disampaikan. Informasi tersebut, yaitu menuliskan hal-hal yang diketahui dan ditanya, membuatkan gambar/sketsa, menggunakan aturan, melakukan perhitungan, dan membuatkan kesimpulan.

Pada keakuratan dan kelancaran komunikasi matematika tertulis siswa laki-laki dan perempuan berkemampuan matematika tinggi adalah sama-sama akurat dan lancar untuk setiap informasi yang disampaikan. Kelengkapan komunikasi matematika tertulis siswa perempuan berkemampuan matematika tinggi adalah lengkap untuk setiap informasi yang disampaikan sedangkan siswa laki-laki hanya tidak lengkap untuk menggunakan aturan. Hasil itu menunjukkan adanya sedikit perbedaan komunikasi matematika tertulis untuk siswa laki-laki dan perempuan berkemampuan matematika tinggi.

Penelitian ini hanya difokuskan pada komunikasi matematika tertulis siswa laki-laki dan perempuan berkemampuan matematika tinggi dalam pemecahan masalah matematika di MA. Selanjutnya disarankan melakukan penelitian lanjutan 
tentang komunikasi matematika tertulis berdasarkan faktor lain, memperluas subjek penelitian, dan komunikasi matematika lisan.

\section{UCAPAN TERIMA KASIH}

Artikel ilmiah ini merupakan luaran dari penelitian dosen pemula tahun 2019 yang didanai oleh Direktorat Riset dan Pengabdian Masyarakat, Direktorat Jenderal Penguatan Riset dan Pengembangan, Kementrian Riset, Teknologi dan Pendidikan Tinggi Republik Indonesia pada kontrak pendanaan bulan April 2019.

\section{DAFTAR PUSTAKA}

Agustyaningrum, N. (2011). Implementasi Model Pembelajaran Learning Cycle 5E Untuk Meningkatkan Kemampuan Komunikasi Matematis Siswa Kelas IX B SMP Negeri 2 Sleman. Prosiding, 1. http://eprints.uny.ac.id/7389/1/p-34.pdf

Asmana, A. T. (2018). Profil Komunikasi Matematika Tertulis dalam Pemecahan Masalah Matematika di SMP Ditinjau dari Kemampuan Matematika. INSPIRAMATIKA: Jurnal Inovasi Pendidikan dan Pembelajaran Matematika, 4(1), 1-12.

Caballero, A., Blanco, L. J., dan Guerrero, E. (2011). Problem solving and emotional education in initial primary teacher education. Eurasia Journal of Mathematics, Science and
Technology Education, 7(4), 281-292. https://doi.org/10.12973/ejmste/75206

Dewi, I. (2009). Profil Komunikasi Matematika Mahasiswa Calon Guru Ditinjau dari Perbedaan Jenis Kelamin. Disertasi tidak diterbitkan. Surabaya: PPs Universitas Negeri Surabaya.

Hirschfeld-Cotton, K. (2008). Mathematical Communication, Conceptual Understanding, and Students' Attitudes Toward Mathematics. Action Research Projects (Paper 4). http://digitalcommons.unl.edu/cgi/viev iewcont.cgi? article $=1011 \&$ context $=\mathrm{ma}$ thmidactionresearch.

Isroil, A., Budayasa, I. K., dan Masriyah. (2017). Profil Berpikir Siswa SMP dalam Menyelesaikan Masalah Matematika Ditinjau dari Kemampuan Matematika. Jurnal Review Pembelajaran Matematika, 2(2), 93105.

http://jrpm.uinsby.ac.id/index.php/jrpm /article/download/34/31

Kim, M. K., dan Noh, S. (2010). Alternative mathematics assessment: A case study of the development of descriptive problems for elementary school in Korea. Eurasia Journal of Mathematics, Science and Technology Education, 6(3), 173-186. http://www.ejmste.com/v6n3/eurasia_v 6n3_kim.pdf

Lestari, R. D., Rahayuningsih, S., dan Wiyono, H. J. (2019). Profil Kemampuan Komunikasi Matematika Tertulis Siswa MA dalam Memecahkan Masalah Permutasi Ditinjau dari Perbedaan Gender. Majamath, 2(1), 56-63. 
http://ejurnal.unim.ac.id/index.php/maj amath/article/download/356/203/

Lutfiyah, S. M., Kartinah, dan Rubowo, M. R. (2018). Profil Pemahaman Konsep Siswa Laki-laki dalam Pemecahan Masalah Matematika Menurut Tahapan Polya. Makalah disajikan pada Seminar Nasional Matematika dan Pendidikan $\left(3^{\text {th }}\right.$ SENATIK), Semarang, 11 Agustus 2018.

http://prosiding.upgris.ac.id/index.php/ senatik2018/senatik18/paper/viewFile/ $2855 / 2682$

NCTM. (2000). Principles and Standards for School Mathematics. School Science and Mathematics (Vol. 47). https://doi.org/10.1111/j.19498594.2001.tb17957.x

Nugroho, M., Setyawati, R. D., dan Sutrisno. (2018). Profil Kemampuan Siswa Laki-laki dalam Memecahkan Masalah Relasi Fungsi. Makalah disajikan pada Seminar Nasional Matematika dan Pendidikan $\left(3^{\text {th }}\right.$ SENATIK), Semarang, 11 Agustus 2018.

http://prosiding.upgris.ac.id/index.php/ senatik2018/senatik18/paper/viewFile/ $2845 / 2672$

Polya, G. (1973). How to Solve It. Princeton University Press (Vol. 30). https://doi.org/10.2307/3609122

Venkatesh Kumar, G., dan Karimi, A. (2010). Mathematics anxiety, mathematics performance and overall academic performance in high school students. Journal of the Indian Academy of Applied Psychology, 36(1), 147-150. http://search.ebscohost.com/login.aspx ?direct $=$ true $\& \mathrm{db}=$ psyh $\& \mathrm{AN}=2010$ 03566-016\& site $=$ ehost-live

Zhu, Z. (2007). Gender differences in mathematical problem solving patterns: A review of literature. International Education, 8(2), 187203. 
Jurnal Edukasi, Volume 5 No.2, Oktober 2019 ISSN. 2443-0455 